\title{
Integrating an Employability Framework to Improve Occupational Self- Efficacy among Trainees of Vocational Training Institutions
}

\author{
Amalia Rahmandani ${ }^{\mathrm{a}}$, Harlina Nurtjahjanti ${ }^{\mathrm{a} *}$, and Dinie Ratri Desiningrum ${ }^{\mathrm{a}}$ \\ ${ }^{a}$ Faculty of Psychology, Universitas Diponegoro, Semarang, Indonesia \\ *Corresponding author: \\ Harlina Nurtjahjanti \\ Faculty of Psychology, Universitas Diponegoro \\ Jl Prof Soedarto, SH, Tembalang, \\ Semarang, Jawa Tengah \\ Indonesia, 50275 \\ Tel.: +6224-7460051 \\ Email address: harlina_nc@yahoo.com
}




\title{
Integrating an Employability Framework to Improve Occupational Self- Efficacy among Trainees of Vocational Training Institutions
}

\begin{abstract}
Both hard skills and soft skills are important for employees to be able to compete and survive in their work. While hard skills can be achieved by further training, efforts to improve soft skills need to be more facilitated. Soft skills are important for increasing one's belief in one's capacity, and as a consequence, it affects the adjustment, performance, satisfaction, and stronger engagement in the workplace. This study aims to examine the effectiveness of an Integrating Employability Framework (IEF) toward occupational self-efficacy among trainees of vocational training institutions. This study used a one-group pretest-posttest quasi-experimental design. Measurements were conducted using the Instrument for Perception of Individual Capacity (Nurtjahjanti, Desiningrum, \& Rahmandani, in press). Forty-one participants were recruited using the cluster sampling method from Balai Besar Pengembangan Latihan Kerja (BBPLK), Semarang, Indonesia. The analysis uses the statistical method of paired-sample t-test between pretest and posttest, showing a significant increase $(t=3.717, p=0.001)$, which indicated the improvement of occupational self-efficacy. These results are evidence that IEF effectively increases occupational self-efficacy. Self-understanding, the appreciation of positive assets, and regular practice and evaluation of problem-solving techniques taught might play important roles in enhancing perceived control and core self-evaluation as well. This then correlates to self-efficacy in judging and making decisions when facing difficult situations. Active and effective coping could be selected as a strategy. Group roles provide therapeutic effects. Subsequent research should consider an effective and efficient design for larger groups, employ a research design providing a higher level of significance, and consider follow up measurement.
\end{abstract}

Keywords: Integrating Employability Framework; career counseling; perception of individual capacity; trainees of vocational training institution

\section{Introduction}

Human Resources (HR) is a valuable asset that deserves to be developed, managed effectively, and empowered for an organization's success and survival. Therefore, it needs to be explored, nurtured, and developed to be utilized as much as possible to improve the welfare of human life. According to the Central Bureau of Statistics (Badan Pusat Statistik/BPS), in 2016, the number of Indonesian employees was 125.44 million, 90\% of whom graduated from high school or below (Romli, 2016). In addition, the level of competitiveness domestically, regionally and locally is still very low. This concern has prompted efforts to increase the level of labor competitiveness and competence; it has triggered the Indonesian Government to establish vocational training institutions that accommodate education for many needed vocational skills. The government has revitalized many aspects of the educational facility (Agus, 2016), including infrastructure, instructors, methods and curriculums, and institution management. Moreover, there are many open opportunities to join free training sessions that are supported by incentives.

While these vocational training institutions successfully promote students' hard skills, the learning patterns of vocational training institutions do not emphasize soft skills enough. Previous inadequacy of hard skills or labor competence was originally believed to be the source of the 
problem, but more recently, it has become clear that inadequacy of hard skills can no longer be used as a justification for employee retention issues such as absenteeism and voluntary turnover. Soft skills contribute to an employee's successful adjustment at work, work style, cognitive adjustment, and mental toughness. One essential element that contributes to work adjustment is a work style that positively correlates to work awareness and engagement (Bayl-Smith \& Griffin, 2015). Another research claims that cognitive adjustment is a vital characteristic of employee mental health, and that it is a necessity for successful adjustment at work, in work groups, and in the organization (Malo, Tremblay, \& Brunet, 2016). Next, mental toughness operates as a stress resilience resource, allowing better adjustment to perceived stress (Gerber et al., 2013) by empowering more effective coping through problem-focused strategies that include less focus on emotion and avoidance (Kaiseler, Polman, \& Nicholls, 2009).

Furthermore, soft skills improvement has an important role in increasing individuals' beliefs about their capacity and evaluation on their ability or competence to perform a task, achieve goals, and overcome existing obstacles. This is referred to as occupational self-efficacy. Selfefficacy itself is the belief in one's ability to successfully complete several tasks. Individuals with good self-efficacy are able to create challenging goals and are strongly committed to achieving them (Bandura, 1994). They also have the confidence to face challenges in achieving the goals. Self-efficacy affects effort, persistence, resilience and achievement (Bandura 1997; Shunck, 1995). In industrial fields, occupational self-efficacy is the predictor for an increase in job engagement and job satisfaction and a decrease in emotional exhaustion (Skaalvik \& Skaalvik, 2014). In turn, increasing job engagement is expected to affect life satisfaction positively (Körner, Reitzle, \& Silbereisen, 2012).

The efforts to increase occupational self-efficacy have become an important issue for organizational development. By improving work readiness and increasing willingness to work harder and the ability to persist when they encounter difficulties in their job, they can achieve self-efficacy at a higher level. The results of a self-efficacy-based intervention can improve many elements of self-efficacy, including engagement, performance, and decreased burnout rates for students (Breso', Schaufeli, \& Salanova, 2010). The intervention in this study used Social Cognitive Theory as the theoretical framework and was based on a cognitive-behavioral approach. They were performed individually and lasted for four months. At the same time, a study on group counseling using a problem-solving approach showed an improvement in educational self-efficacy in students (Sohrabi, Mohammadi \& Aghdam, 2013). For a business organization, efforts to increase self-efficacy in the shorter term and/or in groups should be planned and executed for improved effectiveness and efficiency.

Career counseling can also increase an employee's self-efficacy. Traditional counseling practices emphasize the assessment of individuals' abilities, aptitudes, personalities, values, and interests to aid them in selecting appropriate educational programs or making occupational choices (Gysbers, Heppner, \& Johnston, 2014); these are considered as separate from other roles in life and personal consent (Amundson, Harris-Bowlsbey, \& Niles, 2014). Nowadays, the meaning of career counseling has been redefined. Career and personal counseling should be further integrated by expanding the role of counseling to overcome personal problems that may be affecting other various roles in life (Zunker, 2006). According to Gysbers, Heppner, and dan Johnston (2014), career counseling is expected to assist individuals in facing life crises and requires at least three things: (1) to predict and develop one's individual career life; (2) to solve 
problems effectively and take preventive and positive measures to focus on strength development; and (3) to ensure stability and change during career development.

Integrating Employability Framework (IEF) is a group-based method of career counseling aimed at helping trainees improve their capacity for occupational self-efficacy. The basis for the module preparation was obtained through an assessment of trainees in the vocational training institution at the Work Training Development Center (Balai Besar Pengembangan Latihan Kerja/ BBPLK) in Semarang, Indonesia. BBPLK is the Central Technical Implementation Unit under the Ministry of Labor, which is responsible for developing training, empowerment, and certification of labor and training personnel, with the goal of creating a competent labor force with a high work ethic (BBPLK Semarang, 2016). Partnerships are created and used to facilitate educated students in finding job opportunities.

IEF uses the basic principles of counseling or psychotherapy with an Adlerian approach that views human nature as creative, active, and decisional. This approach focuses on the unity of the individual, on understanding the individual's subjective perspective, and on the importance of life goals that lead to improved behavior or performance. Adler (Corey, Corey, \& Corey, 2014) holds that inherent feelings of inferiority initiate a natural striving action toward achieving a higher level of mastery and competence in life. In an industrial setting, feelings of inferiority may be represented by low occupational self-efficacy. Employees are expected to continuously achieve higher levels of mastery and skills, especially to handle workplace challenges.

The process of implementing the IEF adapts the process of counseling or psychotherapy as practiced by Adlerians, which has four goals (Mosak \& Maniacci, 2011): (1) establishing and maintaining a good relationship; (2) uncovering the dynamics of the patient, including their lifestyle and goals, as well as assessing how they affect life movement; (3) interpreting culmination in insight; and (4) reorientation. While in the group, the Adlerian counseling consists of four stages (Sonstegard, Bitter, \& Pelonis, 2004): (1) group relationship formation (2) psychological investigation within the group; (3) psychological disclosure within the group; and (4) group reorientation. Reorientation teaches techniques for developing a holistic and healthy lifestyle that helps overcome feelings of inferiority (Gladding, 2009). The various techniques used are not limited to a specific set of procedures; rather, individuals can tap their creativity by applying the most appropriate techniques for each client (Corey et al., 2014). Adlerians are likely to borrow techniques from other therapies when they feel that they might be effective, as long as they are consistent with Adlerian principles (Sharf, 2012).

Compared to other interventions, IEF counseling is conducted with more participants in group format and has a shorter term, with only 4 consecutive meetings. Therefore, it is expected to support effectiveness and efficiency in the organization. In addition to considering the role of groups in an effort to increase occupational self-efficacy, IEF takes individuality into account; that is, paying attention and including attention to personal problems. This aligns with the redefinition of career counseling described above.

This study aimed to test the effectiveness of IEF in increasing occupational self-efficacy among vocational training institution trainees. The hypothesis of this study was that IEF was effective in increasing trainees' perceptions of their individual capacities. The implementation of IEF in this study involved students from BBPLK in Semarang, Indonesia and used the cluster sampling 
technique. This one group quasi-experimental study was conducted with a total of 41 participants. Measurements of occupational self-efficacy were taken twice: once before and once after the intervention.

\section{Methods}

\section{Participants}

Participants in this study were trainees of a vocational training institution in BBPLK, Semarang, Indonesia, who were undergoing an early stage of education. Participants were not limited in terms of age or gender given the diversity of the conditions likely to occur in BBPLK. However, it reflects the reality in the field. Taking into account these limitations, an additional analysis of the difference in gain scores observed from these two variables is provided to illustrate the effect. Using the cluster sampling technique, participants were trainees who were studying for graphic design, technical support, audio/video, and automotive engineering majors. The acquisition of the clusters was the result of randomization; the cluster sampling technique is included in the list of alternative methods for random sampling (Clark-Carter, 2004). Prior to the study, the trainees listened to the explanation of the study and expressed willingness to voluntarily engage in the research by signing an informed consent. The number of participants attending the first meeting was 56. These were divided into nine counseling groups, each of which had six or seven people. By the time the intervention ended, a total of 15 participants were excluded because they did not participate in the complete set of intervention meetings. Therefore, the number of participants with data that could be processed was 41 trainees $\left(\mathrm{M}_{\mathrm{age}}=23.02 ; \mathrm{SD}=6.19\right)$.

As seen in Table 1, the data shows that 78\% $\left(n=32 ; M_{\text {age }}=23.92 ; \mathrm{SD}=7.29\right)$ of the participants were male, while $22 \%\left(\mathrm{n}=9 ; \mathrm{M}_{\mathrm{age}}=22.78 ; \mathrm{SD}=6.49\right)$ were female. Ten participants were adolescents (17-20 years old) with work experience, while seven participants in their early adulthood (21-35 years old) had no experience in working over the time period since their graduation, which varied from two to nine years. From the 30 participants with work experience, three participants had jobs that were not relevant to their educational backgrounds, while the rest had worked in accordance with or supported by their educational backgrounds.

Table 1

Characteristics of Research Participants

\begin{tabular}{|c|c|c|c|c|c|}
\hline \multirow[b]{2}{*}{ Characteristics } & \multicolumn{4}{|c|}{ Major } & \multirow[b]{2}{*}{ Total $(\mathrm{n}=41)$} \\
\hline & $\begin{array}{c}\text { Graphic Design } \\
(\mathrm{n}=14)\end{array}$ & $\begin{array}{l}\text { Technical Support } \\
(\mathrm{n}=12)\end{array}$ & $\begin{array}{c}\text { Audio-Video } \\
(\mathrm{n}=10)\end{array}$ & $\begin{array}{c}\text { Automotive } \\
(\mathrm{n}=5)\end{array}$ & \\
\hline \multicolumn{6}{|c|}{ 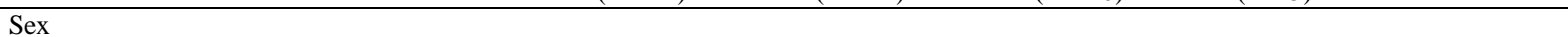 } \\
\hline Male & 7 & 12 & 9 & 4 & 32 \\
\hline Female & 7 & 0 & 1 & 1 & 9 \\
\hline \multicolumn{6}{|l|}{ Age } \\
\hline $17-20$ & 2 & 5 & 4 & 2 & 13 \\
\hline $21-35$ & 12 & 6 & 3 & 3 & 24 \\
\hline$\geq 36$ & 0 & 0 & 3 & 0 & 3 \\
\hline Ūnknown & 0 & 1 & 0 & 0 & 1 \\
\hline \multicolumn{6}{|l|}{ Educational Background } \\
\hline Junior High School/similar degree & 0 & 0 & 1 & 2 & 3 \\
\hline Senior High School/similar degree & 6 & 10 & 5 & 3 & 24 \\
\hline Diploma & 0 & 0 & 2 & 0 & 2 \\
\hline Bachelor & 8 & 1 & 2 & 0 & 11 \\
\hline Unknown & 0 & 1 & 0 & 0 & 1 \\
\hline \multicolumn{6}{|l|}{ Year of Graduation } \\
\hline$\leq 2002$ & 0 & 0 & 2 & 0 & 2 \\
\hline 2003-2006 & 0 & 0 & 1 & 0 & 1 \\
\hline
\end{tabular}


Table 1, cont.

Characteristics of Research Participants

\begin{tabular}{|c|c|c|c|c|c|}
\hline \multirow[b]{2}{*}{ Characteristics } & \multicolumn{4}{|c|}{ Major } & \multirow[b]{2}{*}{ Total $(n=41)$} \\
\hline & $\begin{array}{l}\text { Graphic Design } \\
(\mathrm{n}=14)\end{array}$ & $\begin{array}{l}\text { Technical Support } \\
(\mathrm{n}=12)\end{array}$ & $\begin{array}{c}\text { Audio-Video } \\
(\mathrm{n}=10)\end{array}$ & $\begin{array}{c}\text { Automotive } \\
(\mathrm{n}=5)\end{array}$ & \\
\hline $2007-2010$ & 2 & 2 & 1 & 1 & 6 \\
\hline 2011-2014 & 4 & 3 & 1 & 0 & 8 \\
\hline$>2015$ & 8 & 5 & 4 & 0 & 17 \\
\hline Ūnknown & 0 & 2 & 1 & 4 & 7 \\
\hline \multicolumn{6}{|l|}{ Marital Status } \\
\hline Married & 0 & 0 & 4 & 0 & 4 \\
\hline Not Married & 14 & 11 & 6 & 5 & 36 \\
\hline Unknown & & 1 & 0 & 0 & 1 \\
\hline \multicolumn{6}{|l|}{ Origin } \\
\hline Semarang City & 11 & 6 & 5 & 2 & 24 \\
\hline Outside Semarang & 3 & 5 & 5 & 3 & 16 \\
\hline Unknown & 0 & 1 & 0 & 0 & 1 \\
\hline \multicolumn{6}{|l|}{ Length of Training } \\
\hline Week 1 & 6 & 9 & 4 & 3 & 22 \\
\hline Week 2 & 8 & 2 & 6 & 2 & 18 \\
\hline Unknown & 0 & 1 & 0 & 0 & 1 \\
\hline \multicolumn{6}{|l|}{ Work Experience } \\
\hline Experienced (Entrepreneur) & 2 & 0 & 5 & 0 & 7 \\
\hline Experienced (Employee) & 6 & 9 & 5 & 3 & 23 \\
\hline Inexperienced & 6 & 2 & 0 & 2 & 10 \\
\hline Unknown & 0 & 1 & 0 & 0 & 1 \\
\hline
\end{tabular}

\section{Research Design}

The design of this research used a quasi-experimental method with one group of pretest-posttest design; the treatment was given to one experimental group with one measurement each during the pre-and-post implementation stages of the treatment (Shadish, Cook, \& Campbell, 2002).

\section{Measures}

Occupational self-efficacy in this research was measured using the Scale of Perception of Individual Capacity (PIC) developed by Nurtjahjanti, Desiningrum, and Rahmandani (in press) of 54 items ( $\left.\mathrm{r}_{\mathrm{ix}}=0.312-0.628 ; \alpha=0.936\right)$. The PIC has been developed in Indonesian and uses the Likert response model consisting of 4 response categories ranging from Strongly Agree (4) to Strongly Disagree (1).

The PIC instrument consists of 5 dimensions, namely: (1) ability to plan for the future; eg, "I deserve the things I have", and "I evaluate myself to turn my weaknesses into strengths"; (2) ability to problem-solve; eg, "I have limitations so I want to push myself to the limit", and "I have targets to keep myself motivated to study"; (3) ability to adjust; eg, "New assignments provide new challenges for me", and "The training instructor provides assistance to motivate me to learn"; (4) confidence for success in the future; eg, "I believe that I have the ability to adapt the changes in the working world nowadays", and "Success in career is a dream to come true"; (5) capability of career planning in organizations; eg, "Perseverance is one of my plans to be successful", and "I will never be discouraged easily when I have difficulties in work".

\section{Procedure}

IEF is a group-based career counseling intervention based on the assessment results from evaluating vocational training institution trainees in BBPLK, Semarang, Indonesia. It uses the basic principles and counseling techniques of the Adlerian approach. The IEF module was tested 
on BBPLK Semarang students with a total of 23 people, and it was revised based on input from facilitators and co-facilitators prior to the implementation of this study.

Participants in this study were divided into several groups, each of which totaled six or seven people. According to Corey, Corey, and Corey (2014), a group of six to eight people is the recommended and ideal number of participants in a group; it is big enough to provide ample opportunity for interaction but small enough for everyone to be involved and to feel a sense of "group". Each group was led by a facilitator and a co-facilitator. Both facilitators and cofacilitators recruited in this study were Bachelors and undergraduate students of the Faculty of Psychology from Diponegoro University. As many as nine pairs accompanied the nine groups. Facilitator qualifications are as follows: (1) undergraduate of psychology; (2) have basic counseling skills; and (3) have experience in managing group counseling. The qualifications of the co-facilitators are as follows: (1) students of psychology within the last year; (2) have graduated in lectures containing assessment (i.e. observation, individual and group interview) and intervention (i.e. various approaches in intervention, individual and group intervention, including counseling) materials; and (3) have experience in assisting the implementation of group counseling. Facilitators and co-facilitators received training for trainers on IEF modules prior to the implementation of the research.

The IEF module initially consisted of six meetings (Nurtjahjanti et al., in press), including: (1) forming a group relationship and facilitating psychological investigation within the group; (2) identifying basic mistakes; (3) understanding self-defeating behaviors; (4) identifying positive assets and exercising positive affirmations; (5) practicing positive affirmations and coping imagery; and in the last session, (6) monitoring and terminating. Meeting duration was between 90 and 120 minutes. Meetings were held twice a week, so the intervention ended within three weeks.

Intervention in this study was ultimately carried out using a four-session version of the IEF (a short version, each approximately 120 minutes) due to field limitations. Specifically, the period of research provided was short (four consecutive days). The tight schedule and limited time period for education were also considered. Four such intervention meetings, including: (1) forming a group relationship, facilitating psychological investigation within the group, and identifying basic mistakes; (2) understanding self-defeating behavior and identifying positive assets; (3) practicing positive affirmations and coping imagery; and in the last session, (4) monitoring and terminating (general goals and details of activities/sessions from each meeting are shown in Table 2).

Homework was provided and requested to be completed before each next intervention meeting; it was administered carefully so that the facilitator did not direct the participants' life (Sharf, 2012); as a means of reflection, practice, self-monitoring, and assistance in delivering the learning process for the next session. Both sharing and homework were provided to facilitate the disclosure of personal issues by each individual. This aligns with the redefinition of career counseling as paying attention to personal issues (Zunker, 2006). 
Table 2

Integrating Employability Framework Intervention Design for Four Sessions

\begin{tabular}{|c|c|c|c|c|}
\hline $\begin{array}{c}\text { Day } \\
\text { (Duration) }\end{array}$ & Topic & General Objective & $\begin{array}{c}\text { Activity/ Session } \\
\text { (Duration in Minutes) }\end{array}$ & Method \\
\hline \multirow[t]{5}{*}{$\begin{array}{c}1 \\
\left(1200^{\prime}\right)\end{array}$} & \multirow[t]{5}{*}{$\begin{array}{l}\text { Forming a group relation, } \\
\text { facilitating psychological } \\
\text { investigation within the } \\
\text { group, and identifying basic } \\
\text { mistakes }\end{array}$} & \multirow[t]{5}{*}{$\begin{array}{l}\text { Opening group counseling, } \\
\text { establishing the conducive group } \\
\text { relations to perform psychological } \\
\text { investigation and identify basic } \\
\text { mistakes }\end{array}$} & $\begin{array}{l}\text { 1. Opening, Introduction, and } \\
\text { Explanation of Group Counseling } \\
\text { Activity (10) }\end{array}$ & $\begin{array}{l}\text { Lecture, Q\&A } \\
\text { session }\end{array}$ \\
\hline & & & $\begin{array}{l}\text { 2. Group Counseling Contract and } \\
\text { Informed Consent (10) }\end{array}$ & \\
\hline & & & 3. "The Questions" (45) & $\begin{array}{l}\text { Reflection, Sharing, } \\
\text { Lecture, Discussion }\end{array}$ \\
\hline & & & 4. Identifying Basic Mistakes (45) & \\
\hline & & & 5. Homework and Closing (10) & $\begin{array}{l}\text { Lecture, Q\&A session, } \\
\text { Summarizing }\end{array}$ \\
\hline \multirow[t]{4}{*}{$\begin{array}{c}2 \\
\left(120^{\prime}\right)\end{array}$} & \multirow[t]{4}{*}{$\begin{array}{l}\text { Understanding self- } \\
\text { defeating behaviors and } \\
\text { identifying positive assets }\end{array}$} & \multirow[t]{4}{*}{$\begin{array}{l}\text { Strengthening participants' } \\
\text { understanding about the effects of } \\
\text { basic mistakes on job-related } \\
\text { expectations and future planning. } \\
\text { Identifying positive assets and } \\
\text { strengthening positive perceptions } \\
\text { of individual ability. }\end{array}$} & $\begin{array}{l}\text { 1. Opening and Homework Review } \\
\text { (20) }\end{array}$ & $\begin{array}{l}\text { Lecture, Review, } \\
\text { Discussion }\end{array}$ \\
\hline & & & $\begin{array}{l}\text { 2. The awareness of Self-Defeating } \\
\text { Behaviors (45) }\end{array}$ & $\begin{array}{l}\text { Reflection, Sharing, } \\
\text { Worksheet, Lecture, }\end{array}$ \\
\hline & & & $\begin{array}{l}\text { 3. Identifying Self-Positive Assets } \\
(45)\end{array}$ & Discussion \\
\hline & & & 4. Homework and Closing (10) & $\begin{array}{l}\text { Lecture, Q\&A session, } \\
\text { Summarizing }\end{array}$ \\
\hline \multirow[t]{4}{*}{$\begin{array}{c}3 \\
\left(120^{\prime}\right)\end{array}$} & \multirow[t]{4}{*}{$\begin{array}{l}\text { Practicing positive } \\
\text { affirmations and coping } \\
\text { imagery }\end{array}$} & \multirow[t]{4}{*}{$\begin{array}{l}\text { Strengthening positive perceptions } \\
\text { of individual ability to overcome } \\
\text { the problem through positive } \\
\text { affirmations and coping imagery }\end{array}$} & $\begin{array}{l}\text { 1. Opening and Homework Review } \\
\text { (30) }\end{array}$ & $\begin{array}{l}\text { Lecture, Review, } \\
\text { Discussion }\end{array}$ \\
\hline & & & 2. Positive Affirmation (20) & $\begin{array}{l}\text { Worksheet, Practice, } \\
\text { Discussion }\end{array}$ \\
\hline & & & 3. Coping Imagery (60) & $\begin{array}{l}\text { Reflection, Worksheet, } \\
\text { Practice, Lecture, } \\
\text { Discussion }\end{array}$ \\
\hline & & & 4. Homework and closing (10) & $\begin{array}{c}\text { Lecture, Q\&A session, } \\
\text { summarizing }\end{array}$ \\
\hline \multirow[t]{3}{*}{$\begin{array}{c}4 \\
\left(120^{\prime}\right)\end{array}$} & \multirow[t]{3}{*}{ Monitoring and termination } & $\begin{array}{l}\text { Monitoring and evaluating the } \\
\text { progress of the participants, } \\
\text { supporting and strengthening } \\
\text { participants' achievements, } \\
\text { terminating group counseling }\end{array}$ & $\begin{array}{l}\text { 1. Opening and Homework Review } \\
\text { (40) }\end{array}$ & $\begin{array}{l}\text { Lecture, Review, } \\
\text { Discussion }\end{array}$ \\
\hline & & & $\begin{array}{ll}\text { 2. } & \text { Reflection (Evaluation and } \\
& \text { Expectation) }(60) \\
\end{array}$ & $\begin{array}{l}\text { Reflection, Worksheet, } \\
\text { Lecture, Discussion }\end{array}$ \\
\hline & & & 3. Termination and Closing (20) & $\begin{array}{c}\text { Sharing, Review, } \\
\text { Worksheet }\end{array}$ \\
\hline
\end{tabular}

The first meeting consisted of a session for forming a group relationship, facilitating psychological investigation within the group, and identifying basic mistakes. The "forming a group relationship" session was made more brief due to necessary explanation of research and group counseling contracts. It contained a number of agreements offered by the facilitator to ensure cooperative relationships during the counseling process (Sonstegard et al., 2004; Sharf, 2012).

The next session consisted of "the questions", which addressed the question of "what if" (Sharf, 2012) or questioned the participants about their expectations about the job, actions they would take when accepted on the job, and the characteristics of the work disliked or to be avoided. The responses to these questions would lead facilitators into the next session of basic mistakes, which 
identified mistakes of fundamental thinking and impacted the emergence of a self-defeating lifestyle (Sharf, 2012). Some categorizations were: (1) overgeneralizations; (2) false or impossible security goals; (3) misperceptions of life and life's demands; (4) minimization or denial of one's worth; and (5) faulty values (Mosak \& Maniacci, 2011).

The second meeting was dedicated to understanding self-defeating behavior and identifying positive assets. Participants were invited to understand the impact of basic mistakes on the emergence of self-defeating behavior more deeply. They learned that self-defeating behavior is not only limited to concrete behavior but also includes a way of thinking and trapping feelings by hanging onto old destructive perception patterns (Sharf, 2012).

The effort to increase participants' awareness of faulty beliefs provided one way of "catching themselves" and convincing them to change their behavior (Sharf, 2012) through techniques that would be taught in the following session, which identified positive assets. Positive assets can include a number of characteristics, such as honesty, attention to others, and positive thought process skills. In some cases, the assets were obvious, while in others, the participant was unaware of his assets (Sharf, 2012).

To facilitate awareness of unconscious assets, participants were provided with opportunities to share and reflect on their experiences that reflected their positive qualities. The facilitator further helped the participants find the exact words or phrases for characteristics about their experiences (positive assets).

The third meeting consisted of practicing positive affirmations and creating coping imagery. The acquisition of positive assets was used as a means to encourage participants by performing positive affirmation exercises. By focusing on beliefs and self-perceptions, the facilitator helped participants overcome feelings of inferiority and low self-concept (Sharf, 2012).

In the next session, coping imagery allowed participants to visualize themselves as coping with an anticipated difficult situation (Curwen, Palmer, \& Rudell, 2008). Adler believed that a mental picture of doing something could have a much stronger impact than simply reminding oneself mentally (Sharf, 2012). This session was divided into two stages. In the first stage, each participant determined the object of their coping imagery; they identified a specific situation for the related problem that they wanted to target directly or indirectly. They also identified which of their individual assets they perceived to be most appropriate to overcome the problem, as well as came up with supporting positive affirmation sentences and specific behaviors and appropriate steps for overcoming the problem. Whenever possible, the targets set would be realized in real time within the interval of the group counseling intervention.

The second stage described the technique and guided the coping imagery. The beginning of the coping imagery guidance resembled a breathing relaxation exercise. Participants were then asked to gradually present the target event, to bear up in difficult situations, to utter positive affirmations, and to gradually visualize each step to overcome the problem successfully, as planned in the previous stage. During practice, participants were also asked to keep track of the rhythm of their breath and to notice the changes occurringinside them at the same time. Evaluation, feedback, and appreciation were conducted to nurture the participants' motivation 
and to optimize subsequent practice. The homework for the third meeting was a form of exercise and self-monitoring of positive affirmations and coping imagery.

In the fourth meeting, facilitator monitoring and termination were conducted. Instead of introducing new techniques, the last meeting was designed to provide a form of continuous encouragement for what the participants had accomplished. Besides reviewing and evaluating the third session's homework, the facilitator and participants, recapped the process of group counseling to provide a clear picture of the participants' perception of the whole intervention (Sharf, 2012). The facilitator provided opportunities for the trainees to reflect on selfdevelopment, obstacles encountered, experience of overcoming obstacles, and how the training fulfilled the participants' expectations at the beginning of group counseling. Furthermore, opportunities were provided to set future goals and expectations as related to jobs, determine the steps to be taken, and remind them to use the exercises they had learned during the counseling process.

\section{Data Analysis}

Data processing was based on the quantitative statistic method using correlated data t-test/ paired-sample t-test. As a prerequisite of parametric statistics, the analysis was performed after the assumption test of normality Kolmogorov-Smirnov showed that the data distribution was normal. Statistical analysis and assumption test was conducted using IBM SPSS for Windows, Version 22.

\section{Results}

As seen in Figure 1, it is understood that IEF intervention was able to increase PIC for about 5.78, from the pretest average: 169.83 to the posttest average: 175.61 .

Figure 1. Comparison of Pretest-Posttest Average

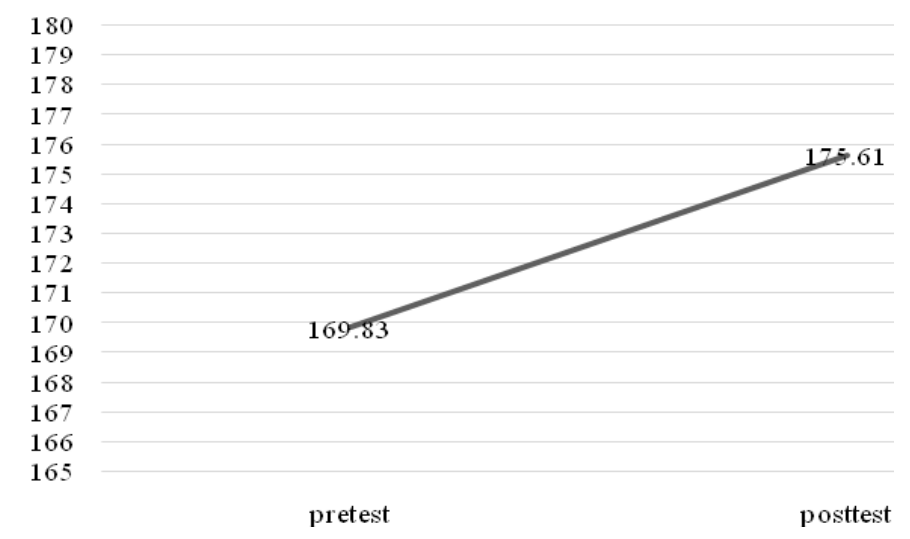

To illustrate the changes in participants as seen on Figure 2, 9 out of 41 participants experienced a decrease in range from 1 to 15 points, while the rest experienced a score increase from 1 to 29 points. 
Figure 2. Comparison of Subject's Pretest-Posttest Score

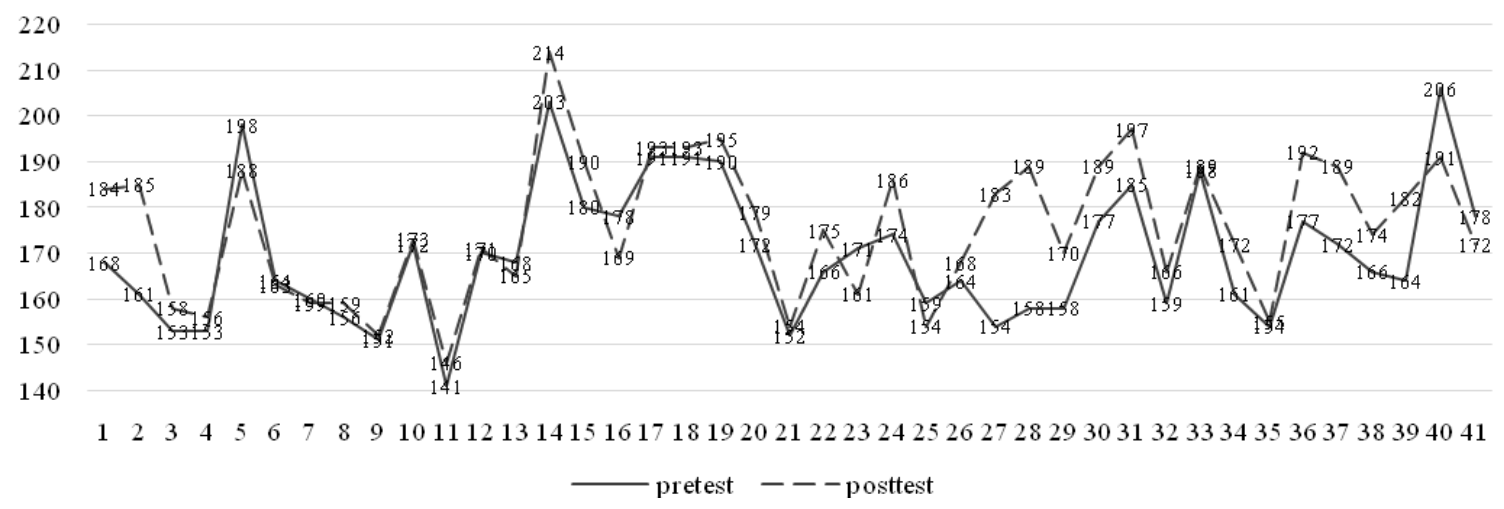

The result of inferential statistical test on the increase of pretest-posttest score as seen in Table 3 shows the value of calculated $\mathrm{t}=3.717$ and $\mathrm{P}=0.001(<0.05)$. It means that the hypothesis is accepted, which means that IEF has a significant effect on increasing PIC with participants.

Table 3

$\underline{\text { Result of Paired Samples Statistical Test }}$

\begin{tabular}{|c|c|c|c|c|c|c|c|c|}
\hline & \multicolumn{5}{|c|}{ Paired Differences } & \multirow[b]{3}{*}{$\mathrm{t}$} & \multirow[b]{3}{*}{ df } & \multirow[b]{3}{*}{ Sig. (2-tailed) } \\
\hline & \multirow[b]{2}{*}{ Mean } & \multirow{2}{*}{$\begin{array}{c}\text { Std. } \\
\text { Deviation }\end{array}$} & \multirow{2}{*}{$\begin{array}{l}\text { Std. Error } \\
\text { Mean }\end{array}$} & \multicolumn{2}{|c|}{$\begin{array}{l}95 \% \text { Confidence Interval of } \\
\text { the Difference }\end{array}$} & & & \\
\hline & & & & Lower & Upper & & & \\
\hline $\begin{array}{l}\text { Pair } 1 \\
\text { Posttest - pretest }\end{array}$ & 5.780 & 9.959 & 1.555 & 2.637 & 8.924 & 3.717 & 40 & .001 \\
\hline
\end{tabular}

Additional analyses were performed to study the difference in gain score in terms of sex, age, length of training, and work experience. After testing the parametric assumptions of normality and homogeneity, non-parametric statistical tests were used to find the difference in gain scores in terms of sex and age, while parametric statistical tests were used in terms of length of training and work experience. Mann-Whitney $U$ test results on gain score between male and female participants obtained $\mathrm{Z}=-0.331$ and $\mathrm{p}=0.740(>0.05)$. Kruskal-Wallis test results on gain score in participants with age 17-20 years, 21-35 years, and 36 years and above obtained values of ChiSquare $=0.282$ and $p=0.868(>0.05)$. Independent Sample t-Test results on gain score based on one week and two week length of training obtained $t=0.143$ and $p=0.887(>0.05)$. While Independent Sample t-Test results on gain score were based on the presence and absence of work experience obtained $t=-0.107$ and $p=0.915(>0.05)$. These four results show that there is no difference in gain score in terms of sex, age, length of training, and work experience. In other words, there is no influence of the four variables on the participant's scores. This also indicates that the decrease in scores for the 9 participants mentioned above was due to other factors which were not observed in this study.

Although the results of this study had limitations such as not able to see the effect of IEF on follow-up measurements some time after intervention ended, the quantitative data shows how IEF significantly affected occupational self-efficacy improvement on posttest as measured by PIC. This result was also supported by the participants' qualitative evaluation of the intervention, 
which was obtained from the response to a worksheet at the last session, which asked participants to: "Share your experience during the group counseling!" Table 4 shows the responses to the question. Data from 41 participants were processed descriptively by separating statements with different meanings and accumulating statements with the same meaning. Each participant could have more than one response. The results show that participants experienced openness, awareness and self-understanding, self-acceptance, a clearer and more positive view of future job role, and an understanding for how to deal with problems in a real and independent way. Some subjects even expressed that they felt more confident and were able to motivate themselves. Sharing and discussions which were conducted as a consequence of group also could not be ignored. These might trigger emotional freedom, mutual understanding and support, and the opportunity to learn from other group members.

Table 4

Participants' Evaluation on Their Experience

\begin{tabular}{|c|c|c|c|}
\hline No & Experience & Quantity & $\%(\mathrm{n}=41)$ \\
\hline 1 & Having fun and enjoying the experience & 7 & 17.1 \\
\hline 2 & Getting new experiences & 3 & 7.3 \\
\hline 3 & Gaining benefits & 2 & 4.9 \\
\hline 4 & Learning new knowledge/understanding about life, especially about job & 12 & 29.3 \\
\hline 5 & $\begin{array}{l}\text { Sharing, having discussions and exchanging motivations (sharing personal problems, } \\
\text { exchanging solutions, valuable knowledge, objectives, challenges) }\end{array}$ & 16 & 39.0 \\
\hline 6 & $\begin{array}{l}\text { Improving social relationships (broadening networks, establishing intimacy, understanding } \\
\text { others/mutual understanding, and learning from the experiences of others) }\end{array}$ & 8 & 19.5 \\
\hline 7 & Accepting problems, obstacles, difficulties encountered & 5 & 12.2 \\
\hline 8 & Identifying, understanding, and introspecting as well as enhancing self-ability & 9 & 22.0 \\
\hline 9 & $\begin{array}{l}\text { Recognizing problems and basic mistakes in having negative thoughts and the impacts in } \\
\text { the future }\end{array}$ & 6 & 14.6 \\
\hline 10 & Acknowledging positive potentials and having positive thoughts in facing challenges & 10 & 24.4 \\
\hline 11 & Realizing the importance or feeling relaxed between daily activities. & 2 & 4.9 \\
\hline 12 & Preparing for a better future by making plans and anticipating possible obstacles & 5 & 12.2 \\
\hline 13 & $\begin{array}{l}\text { Identifying techniques to solve problems evidently and individually through positive } \\
\text { affirmation, relaxation, and mental imagery (decreasing anxiety and increasing relaxed } \\
\text { feeling) }\end{array}$ & 14 & 34.1 \\
\hline 14 & $\begin{array}{l}\text { Increasing self-confidence (being more confident and courageous in extending opinion, } \\
\text { facing challenges, new environment and new people, being able to adapt better, } \\
\text { performing tasks, living life and facing challenges, finding solutions, and making plans to } \\
\text { achieve the targets) }\end{array}$ & 6 & 14.6 \\
\hline 15 & Being able to do self-motivation (to be stronger, better, and positive) & 5 & 12.2 \\
\hline 16 & Experiencing obstacles (uninterested, bored, preoccupied) & 2 & 4.9 \\
\hline 17 & $\begin{array}{l}\text { Reinforcing experience (willingness to get involved/internal motivation, openness, } \\
\text { conducive/ pleasant situation) }\end{array}$ & 6 & 14.6 \\
\hline
\end{tabular}

\section{Discussion}

This study's goal was to examine the effectiveness of IEF in increasing occupational selfefficacy among trainees of a vocational training institution. The hypothesis of this study was that IEF was effective in increasing the trainees' perception of individual capacity. The results show that IEF intervention increased occupational self-efficacy, as indicated by a significant increase of PIC $(\mathrm{t}=3.717, \mathrm{p}=0.001)$. This explains why the proposed hypothesis was accepted. Increased perception of individual self-capacity might be the result of increased perceived control in actual or future situations. Perceived control focuses on beliefs involving influence, including beliefs in influence over one's own actions, as well as contingency beliefs that a given response will influence an outcome (Chipperfield, Perry, \& Stewart, 2012). IEF stages were accompanied by the objective of each stage, which was to facilitate the improvement of 
perceived control by trainees. The accomplishment of these objectives was also supported by the qualitative data from participants' evaluations.

Increased feelings of control and emotional competence were expected to help participants deal with occupational stress by adopting active and effective coping strategies (Bowman \& Stern, 1995; Por, Barriball, Fitzpatrick, \& Roberts, 2011). Moreover, this study provides evidence that the IEF could be used to improve trainees' positive core self-evaluations. Individuals with high positive core self-evaluations perceive fewer stressors, experience less strain after controlling for stressors, and engage in less avoidance coping (Kammeyer-Mueller, Jugde, \& Scott, 2009). Both perceived control and core self-evaluation are concepts related to one's self-efficacy (Chipperfield et al., 2012; Kammeyer-Mueller et al., 2009).

The group itself provided a therapeutic effect for its members. They were able to deepen their self-knowledge through disclosing themselves to others, experiencing a healing force, and gaining new insights that often lead to desired life changes (Corey et al., 2014). The group facilitated the forming of a climate of support, bonding, sharing of experience, mutuality within the group, a sense of belonging, warmth and closeness, and caring and acceptance. The group cohesion even fostered action-oriented behavior such as giving and receiving feedback, a willingness to take risks, and translating insight into action (Corey et al., 2014).

There were 9 participants out of 41 who experienced decreases in score. Additional analyses showed that there were no significant differences in the groups in terms of $\operatorname{sex}(\mathrm{Z}=-0.331, \mathrm{p}=$ $0.740)$, age (Chi-Square $=0.282, \mathrm{p}=0.868)$, length of training $(\mathrm{t}=0.143, \mathrm{p}=0.887)$, and work experience $(\mathrm{t}=-0.107, \mathrm{p}=0.915)$. This means that in terms of the four variables, gain score did not show any difference, so the decrease of score for these 9 participants was due to other factors which were not observed in this study. Additionally, the group may face setbacks during the final stage (Corey et al., 2014). Group members will not always get what they expect from their encounters, even with hard work and commitment. This may happen for various reasons. The termination of the intervention experience itself is impressive for the participants. Corey et al. (2014) explains that they might present themselves as distant, problematic, and argumentative. In some cases, they diminish the work that they themselves or other members have accomplished. Corey et al. (2014) added that it is not realistic to assume that all the issues that were explored will have been worked through. Assisting members in creating a support system is a good way to help them deal with setbacks and stay focused on what they need to do to accomplish their goals. It is important for them to realize that even a small change is a positive first step in a new direction.

Considering the redefinition of career counseling, IEF as a group counseling method that accommodates personal problems and perspectives is an advantage of this career counseling activity (Zunker, 2006; Amundson, et al., 2014). However, it may be challenging for subsequent research to create a more effective and efficient intervention design that can handle a larger group and more subjects.

Although the research had a short range of measurements to deal with the internal validity problem (Shadish et al., 2002), such as history and maturation, subsequent research should consider a design that provides a higher significance level, like designing and administrating a 
double pretest or assigning a control group. Follow-up measurements can also be applied to measure the continuity of treatment effects assigned over longer periods of time.

Seeing the effectiveness of IEF in improving occupational self-efficacy, it is expected that IEF can be integrated into the curriculum of vocational training centers. Instructors are expected to provide opportunities for trainees to develop self-understanding and skills in assessing their capacity as well as to use active and effective coping strategies for adjusting to work environments.

\section{References}

Agus, R. (2016, March 29). Kemenaker targetkan revitalisasi 70 Balai Latihan Kerja selama 2016. Bisnis.com. Retrieved from http://industri.bisnis.com/read/20160329/12/532438/kemenaker-targetkan-revitalisasi-70-balai-latihan-kerja-selama-2016

Amundson, N. E., Harris-Bowlsbey, J., \& Niles, S. G. (2014). Essential elements of career counseling: Processes and techniques, 3rd edition. Canada: Pearson Education.

Bandura, A. (1997). Self-efficacy: The exercise of control. New York, NY: Freeman.

Bandura, A. (1994). Self-efficacy. Retrieved from https://www.uky.edu/-eushe2/Bandura/Bandura1994EHB.pdf

Bayl-Smith, P. H., \& Griffin, B. (2015). Measuring work styles: Towards an understanding of the dynamic components of the theory of work adjustment. Journal of Vocational Behavior, 90, 132-144. doi:10.1016/j.jvb.2015.08.004

BBPLK Semarang. (2016). Profile BBPLK Semarang. Retrieved from http://bbplksemarang.com/profile-bbplk-semarang/

Bowman, G. D., \& Stern, M. (1995). Adjustment to occupational stress: The relationship of perceived control to effectiveness of coping strategies. Journal of Counseling Psychology, 42 (3), 294-303. doi:10.1037/0022-0167.42.3.294

Breso', E., Schaufeli, W. B., \& Salanova, M. (2010). Can a self-efficacy-based intervention decreased burnout, increase engagement, and enhance performance? A quasi-experimental study. Higher Education, 61, 339-355. doi: 10.1007/s10734010-9334-6

Chipperfield, J. G., Perry, R. P., \& Stewart, T L. (2012). Perceived control. In V. S. Ramachandran (Ed.), Encyclopedia of human behavior, second edition: Vol. 3 (pp. 42-48). doi: 10.1016/B978-0-12-375000-6.00109-9

Clark-Carter, D. (2004). Quantitative psychological research: a student's handbook. New York: Psychology Press.

Corey, M. S., Corey, G., \& Corey, C. (2014). Groups, process and practice, ninth edition. Belmont, CA: Brooks/Cole, Cengage Learning.

Curwen, B., Palmer, S., \& Rudell, P. (2008). Brief cognitive behaviour therapy. London: SAGE Publications.

Gerber, M., Brand, S., Feldmeth, A. K., Lang., C., Elliot, C., Holsboer-Trachsler, E., \& Pühse, U. (2013). Adolescents with high mental toughness adapt better to perceived stress: A longitudinal study with Swiss vocational students. Personality and Individual Differences, 54, 808-814. doi: 10.1016/j.paid.2012.12.003

Gladding, S. T. (2009). Counseling: a comprehensive profession, sixth edition. New Jersey: Pearson Education.

Gysbers, N. C., Heppner, M. J., \& Johnston, J. A. (2014). Career counseling: holism, diversity, and strengths. Fourth edition. Alexandria, VA: American Counseling Association.

Kaiseler, M., Polman., R., \& Nicholls. (2009). Mental toughness, stress, stress appraisal, coping and coping effectiveness in sport. Personality and Individual Differences, 47, 728-733. doi: 10.1016/j.paid.2009.06.012

Kammeyer-Mueller, J. D., Jugde, T. A., \& Scott, B. A. (2009). The role of core self-evaluations in the coping process. Journal of Applied Psychology, 94 (1), 177-195. doi: 10.1037/a0013214

Körner, A., Reitzle, M., \& Silbereisen, R. K. (2012). Work-related demands and life satisfaction: The effects of engagement and disengagement among employed and long-term unemployed people. Journal of Vocational Behavior, 80, 187-196. doi:10.1016/j.jvb.2011.05.004

Malo, M., Tremblay, I., \& Brunet, L. (2016). Cognitive adjustment as an indicator of psychological health at work: Development and validation of a measure. Journal of Vocational Behavior, 92, 33-43. doi:10.1016/j.jvb.2015.11.005

Mosak, H. H., \& Maniacci, M. (2011). Adlerian psychotherapy. In R. J. Corsini \& D. Wedding (Eds.), Current psychotherapies: Ninth edition (pp. 67-112). Belmont, CA: Brooks/Cole, Cengage Learning.

Nurtjahjanti, H., Desiningrum, D. R., \& Rahmandani, A. (in press). Measuring instrument for perception of individual capacity: An government training institution example. International Journal of Applied Business and Economic Research.

Shadish, W. R., Cook, T. D., \& Campbell, D. T. (2002). Experimental and quasi-experimental designs for generalized causal inference, 2nd edition. Boston, MA: Houghton Mifflin Company.

Por, J., Barriball. L., Fitzpatrick, K. \& Roberts, J. (2011). Emotional intelligence: Its relationship to stress, coping, well-being and professional performance in nursing students. Nurse Education Today, 31, 855-860. doi:10.1016/j.nedt.2010.12.023

Romli, M. (2016). Maftuchan: Kapasitas keterampilan pekerja Indonesia masih rendah. Forum Demokrasi Nusantara. Retrieved from http://www.forumdemokrasi.com/maftuchan-kapasitas-keterampilan-pekerja-indonesia-masih-rendah/ 
Schunk, D. H. (1995). Self-efficacy, motivation, and performance. Journal of Applied Sport Psychology, 7(2), $112-137$. Retrieved from: https://pdfs.semanticscholar.org/5b0f/dd0ea7a7a80d06dd1631c90634d23bf34e5e.pdf

Sharf, R. S. (2012). Theories of psychotherapy and counseling: Concepts and cases, 5th edition. Belmont, CA: Brooks/Cole, Cengage Learning.

Skaalvik, E. M., \& Skaalvik, S. (2014). Teacher self-efficacy and perceived autonomy: Relations with teacher engagement, job satisfaction, and emotional exhaustion. Psychological Reports: Employment Psychology \& Marketing, 114 (1), 68-77. doi:10.2466/14.02.PR0.114k14w0

Sohrabi, R., Mohammadi, A., \& Aghdam, G. A. (2013). Effectiveness of group counseling with problem solving approach on educational self-efficacy improving. Procedia - Social \& Behavioral Sciences, 84, 1782-1784. doi: 10.1016/j.sbspro.2013.07.033

Sonstegard, M. A., Bitter, J. R., \& Pelonis, P. (2004). Adlerian group counseling and therapy, step-by-step. New York, NY: Brunner-Routledge.

Zunker, V. G. (2006). Career counseling, a holistic approach, 7th edition. Belmont, CA: Thompson Brooks/Cole. 